\title{
Study of Polish Women's Web Portals
}

\section{Andrzej Małachowski and Paulina Przygrodzka University of Economics, Wroclaw, Poland}

\section{andrzej.malachowski@ue.wroc.pl; paulina.przygrodzka@gmail.com}

\begin{abstract}
Results of own research and other studies on Polish women's web portals are presented. The scope of research included primarily content analysis and the range of usability functions available on websites addressed to Polish women. A large part of the research covers women's preference analysis in relation to content offered on websites. Statistical data illus trated the results. The results of this author's research and other studies presented in this paper describe the specific ity of interests of Polish web-surfing women in relation to the content and functionality of web sites addressed predominantly to women. The most important conclusions from research are presented, to use predominantly by website developers and administrators.
\end{abstract}

Keywords: women's web portals, content analysis, usability functions.

\section{Introduction}

The Internet has grown to be the largest medium of communication in the modern world. Online communication, both in bus iness and non-business settings, creates favorable conditions for development of diverse online communities (Boyd \&Ellison, 2007; Geidner et al., 2007). based on shared interests, desires, expectations, ideas, and so on. A good illustration of this trend is the formation of women's communities, as a manifestation of the gender factor in online activities. Many research studies (e.g. Boyd \&Ellison, 2007; Malachowski, 2005; Mendes et al., 2004) confirm that, in relation to the overall population of Internet users, women's online communities display certain specificity, in respect to the range of interests and content preferences as well as functions and practical use of online resources. Below, a fundamental range of themes in Polish women's web portals presented, accompanied by the evaluation of content structure as reported by female expert Internet users. A large part of the paper involves the identification of women's preferences (expectations) in regard to content offered by web portals addressed to women.

\section{Women's Web Community Portals}

There has been a marked growth of Polish community services offered on the Internet in the recent years. The largest online community, nasza-klasa.pl (despite only 2 years of operation!) has managed to attract more than a half of

Material published as part of this publication, either on-line or in print, is copy righted by the Informing Science Institute. Permission to make digital or paper copy of part or all of these works for personal or classroom use is granted without fee provided that the copies are not made or distributed for profit or commercial advantage AND that copies 1) bear this notice in full and 2) give the full citation on the first page. It is permissible to abstract these works so long as cred it is given. To copy in all other cases or to republish or to post on a server or to redistribute to lists requires specific permission and pay ment of a fee. Contact Publisher@InformingScience.org to request redistribution permission.

Polish Internet users. Table 1 shows an overview of the most popular community portals in Poland. 
Table 1: Ranking of Polish community portals

\begin{tabular}{|c|c|c|c|c|}
\hline No. & Portal & $\begin{array}{c}\text { Real use rs } \\
\text { (in m.) }\end{array}$ & $\begin{array}{c}\text { Portal visits (in } \\
\text { m.) }\end{array}$ & \% of all use rs \\
\hline 1 & nasza-klasa.pl & 7.2 & 6,002 & $50.2 \%$ \\
\hline 2 & Onet.pl - Spolecznosci & 3.9 & 161 & $27.6 \%$ \\
\hline 3 & Grupa Fotka.pl-fotka.pl & 3.1 & 2,686 & $22.0 \%$ \\
\hline 4 & Moja Generacja & 3.1 & 138 & $21.8 \%$ \\
\hline 5 & Gazeta.pl - Spolecznosci & 3.0 & 74 & $21.0 \%$ \\
\hline 6 & peb.pl & 1.8 & 53 & $12.5 \%$ \\
\hline 7 & Interia.pl - Spolecznosci & 1.7 & 6 & $12.1 \%$ \\
\hline 8 & Google-blogger.com & 1.7 & 18 & $11.7 \%$ \\
\hline 9 & o2.pl - Spolecznosci & 1.6 & 16 & $11.3 \%$ \\
\hline 10 & Wirtualna Polska - Spolecznosci & 1.5 & 33 & $10.5 \%$ \\
\hline
\end{tabular}

Source: (“Badanie Megapanel,” 2008)

It is worth noting that out of the ten most frequently visited Polish web portals listed above, only top four reach more than one million hits per month, and as such may be consider popular. The last four portals on the list have visits, on average, less than 30 times per month per user, i.e. less than once a day. Moreover, Table 1 does not reflect the gender. Statistics of Polish Internet users by gender and age group is shown in Figure 1.

As shown in Figure 1, Polish women are a marked majority of Internet users in the age group of $15-34(30.5 \%: 24.5 \%)$. In this group, the number of female Internet users is higher by $1 / 4$ com-

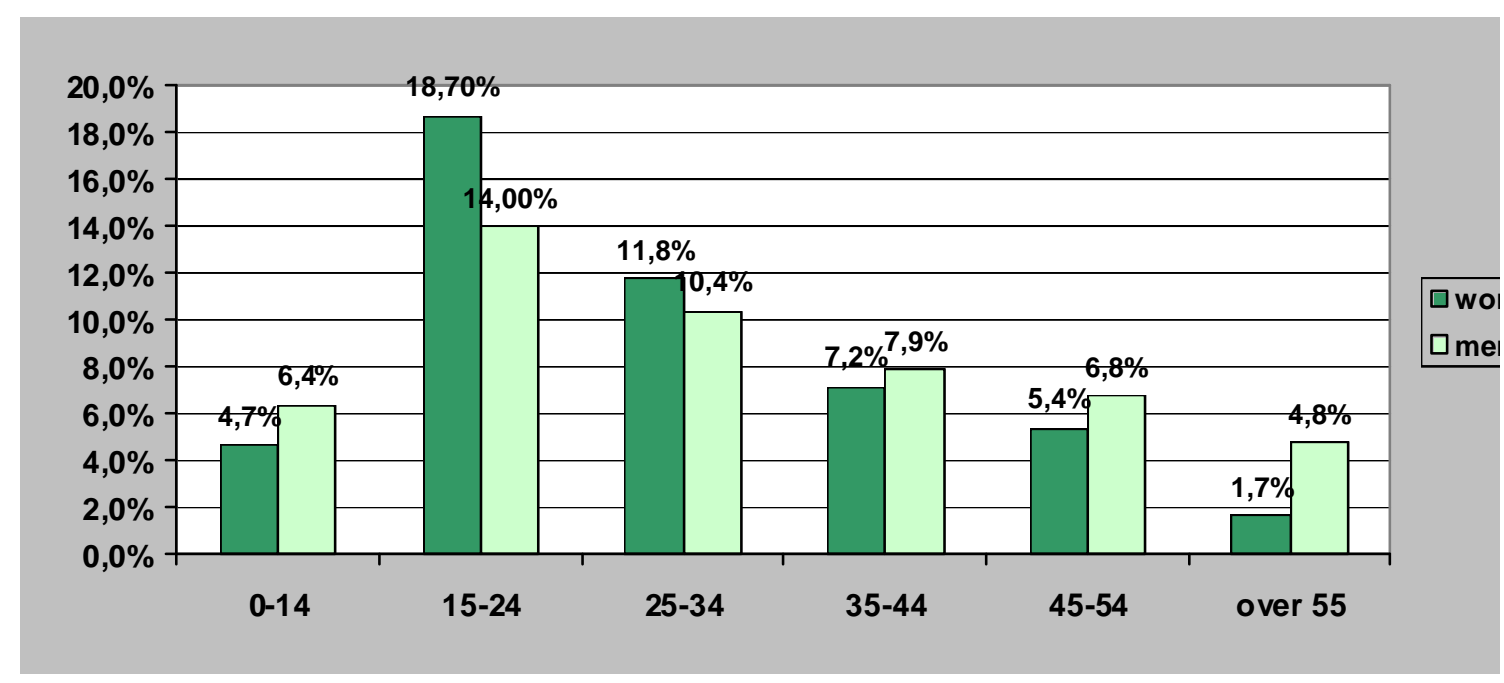

Fig. 1. Distribution of Polish Internet users by ge nder and age group Source: ('Badanie Megapanel", 2007) 
pared to men. This trend is also distinct in the extended age bracket of $15-44$ (37.2\% : 32.4\%, respectively). Female population in this range is nearly $\{(37.2: 32.4) \times 100 \%\} 15 \%$ larger than that of men.

Thus, in the most active age bracket (education, work, family), Polish women constitute a marked majority of Internet users. Moreover, as shown in readily available reports on the subject, Polish women on average are more educated (secondary, bachelor's or master's) than their male counterparts. Obvious ly, web content providers and portal administrators should consider these remarks.

In this respect, it may be interesting to examine the actual content offered on web portals addressed to Polish women.

Table 2: Ranking of portals reporting the highest share of women in the ove rall user structure

\begin{tabular}{|c|c|c|}
\hline No. & Portal & \% of women visiting \\
\hline 1 & elouai.com & $91.6 \%$ \\
\hline 2 & alwaysfresh.pl & $91.4 \%$ \\
\hline 3 & enext.pl & $90.0 \%$ \\
\hline 4 & twojstyl.pl & $88.9 \%$ \\
\hline 5 & magazyn13.pl & $87.8 \%$ \\
\hline 6 & dbp.wroc.pl & $87.3 \%$ \\
\hline 7 & zabawki-swiata.pl & $87.1 \%$ \\
\hline 8 & szybkopraca.pl & $86.4 \%$ \\
\hline 9 & avonpolska.pl & $86.1 \%$ \\
\hline 10 & sennik.org.pl & $86.1 \%$ \\
\hline
\end{tabular}

Source: (“Badanie Megapanel”, 2006)

As shown in the ranking of portals reporting the highest share of women in the overall user structure (Table 2), interests of Polish women are wide and varied.

It is surprising to find the only foreign portal on the list score highest. The Canadian portal www.elouai.com hosts applets that help design dolls, emoticons and icons used in e-mails and on websites. Other portals on the list represent product websites (cosmetics, sanitary pads, toys, etc.) and women's magazines. A job portal (No. 8: szybkopraca.pl) and a fortune-telling portal with horoscopes and dream interpretations (No 10: sennik.org.pl) also scored high on popularity among women.

In the structure of Internet preferences, as demonstrated by PBI/Gemius research study ("Badanie Megapanel', 2006), the most popular women's topics include lifestyle, web communities, education, tourism and employment. Women also take interest in portals addressed to feminine population, with content such as fashion and beauty, childcare, housekeeping. Typical sections of 
women's portals follow similar pattern of health, beauty, culture, makeup, fashion, home, children, erotica, diets, wedding and cuisine. This trend is obviously related to typical information needs and interests of women.

\section{Content and Functional Aspects of Women's Web Portals}

This author's research study was designed and conducted based on the women's web portal reports presented above to provide a detailed analys is of content and functionality of those portals that attract the majority of Polish women. A sample of responders, selected using targeted random sampling, cons isted of 174 women (experts) with considerable experience of using Polish women's portals. The sample was large, well above the limit suggested by J.Nielsen (Nielsen, 2003; Nielsen \&Loranger, 2007) for expert user groups (8-10 responders). The majority of the responders $(88 \%)$ were within the age bracket of 15-44, nearly $90 \%$ of the sample are educated women (secondary, bachelor's or master's) (Przygrodzka, 2008). As such, the sample group was a fair representation of relatively young and educated women. Surveys were distributed via Internet. In the research sample, almost $97 \%$ of the responders use the Internet on a daily basis or at least several times per week.

First, responders' preferences were determined in relation to content that should be included in web portals addressed to women. List of a priori subjects were presented, which was ordered by the responding experts to reflect their interests and preferences. Responders allowed supplementing the list with their own suggestions (content ranges). After normalization (to 100\%), webcontent preferences of Polish women were found to be as depicted on Figure 2.

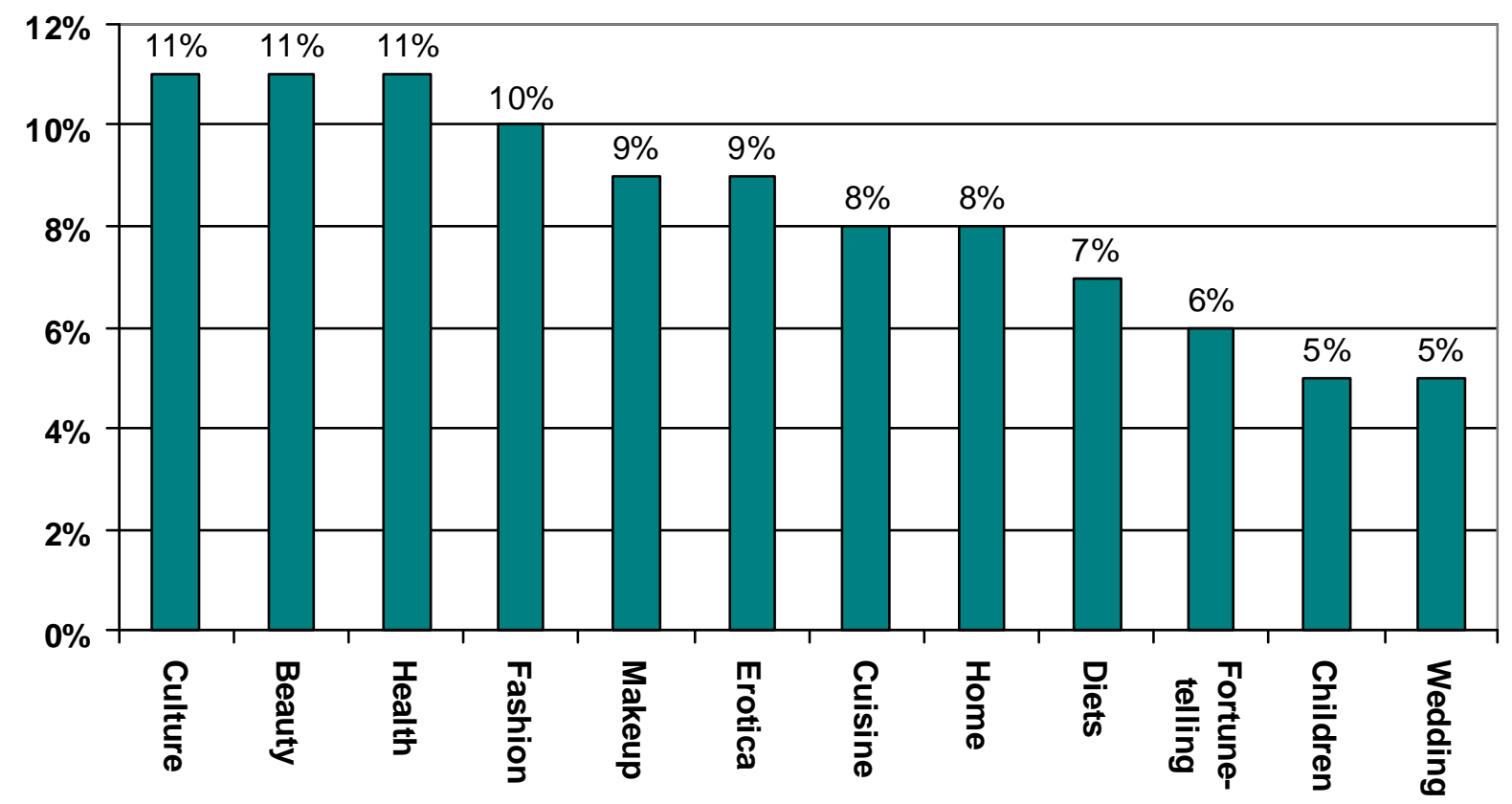

Figure 2. Content preferences and functionality of women's web portals Source: own research 
Content related to health, beauty, culture and fashion scored highest on the list of preferences. Lower scores found in relation to such subjects as makeup, erotica, cuisine and home. The least popular subject themes were those related to dieting, fortune telling, children and wedding.

Supplementary interests (content ranges) are shown on Figure 3 (again, after normalization to $100 \%$ ). As much as $28 \%$ of the responders expressed their interest in work-related issues (job offers, job advert is ing and counse ling). Other topic suggested by responders as appropriate for women's web portals included psychology, tourism, sports and recreation - these found to be consistent with other studies of Polish web-surfing women. Interestingly, as much as $8 \%$ of the responders expressed their interest in automotive news. Interest with celebrity news is found on par. Moreover, $7 \%$ of the responders were interested in legal counseling. The lowest scores obtained in relation to pets, website forums and online shopping. Low interest in the latter two topics is particularly surprising.

Subsequently, we asked the responders to evaluate the content of selected 'typical' women's web portals in Poland, in accordance with the structure of preferences shown on Figure 3. Results of the evaluation show in Table 3.

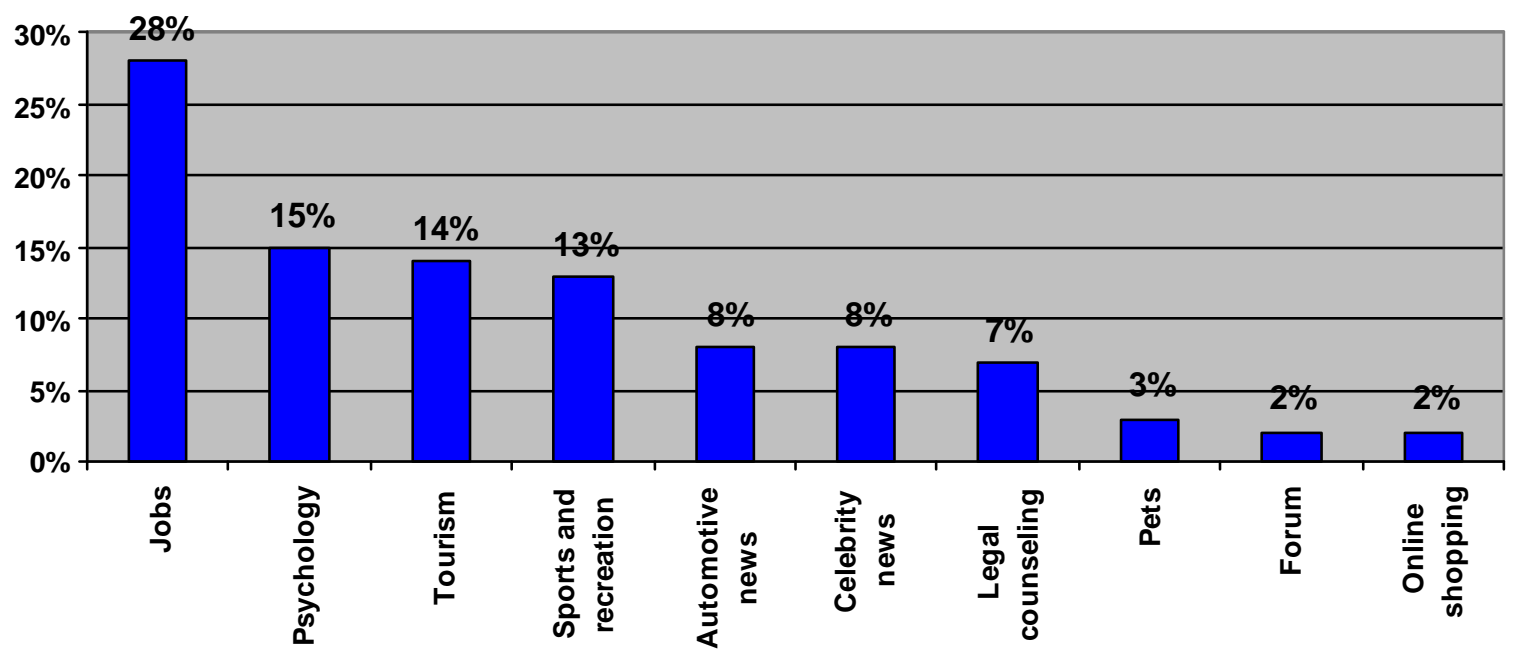

Figure 3: Supplementary preferences in relation to content and functionality of web portals Source: own research

Portal we-dwoje.pl obtained the highest (8.2) average score of content in expert responders' opinion. Portal polki.pl placed second, with a slightly lower score (7.8), while the remaining portals were in the range of medium average (4.4-5.9). The 'ideal' benchmark score of a hypothetic portal with top ranks in all the categories would place at 9.1. This measure (91\% of top scores) is a reference point for web designers, developers and web site administrators in the ir choice of solutions, content and functionality that best suits the preferences of web-surfing women in Poland. These results can also be useful for content providers and e-marketing managers, or e-business managers in general. 
Table 3: Evaluation of content offered on women's web portals

\begin{tabular}{|l|c|c|c|c|c|c|}
\hline \multirow{2}{*}{ Content } & \multicolumn{5}{|c|}{ Portals } & \\
\cline { 2 - 8 } & wizaz.pl & we-dwoje.pl & polki.pl & byckobieta.pl & obcasy.pl & Max \\
\hline Culture & $\mathrm{X}$ & $\mathbf{7}$ & 6 & $\mathrm{X}$ & $\mathbf{7}$ & 7 \\
\hline Beauty & $\mathbf{9}$ & $\mathbf{9}$ & $\mathbf{9}$ & 5 & 4 & 9 \\
\hline Health & 4 & 8 & $\mathbf{1 0}$ & 6 & 4 & 10 \\
\hline Fashion & 4 & 9 & $\mathbf{1 0}$ & 6 & 6 & 10 \\
\hline Makeup & $\mathbf{1 0}$ & 6 & 8 & $\mathrm{X}$ & 3 & 10 \\
\hline Erotica & $\mathrm{X}$ & 7 & $\mathbf{1 0}$ & $\mathrm{X}$ & 5 & 10 \\
\hline Cuisine & $\mathrm{X}$ & $\mathbf{1 0}$ & 8 & 4 & 3 & 10 \\
\hline Ho me & $\mathrm{X}$ & $\mathbf{8}$ & 6 & $\mathbf{8}$ & 7 & 8 \\
\hline Diets & 2 & $\mathbf{8}$ & $\mathbf{8}$ & $\mathbf{8}$ & 4 & 8 \\
\hline Fortune-telling & $\mathrm{X}$ & $\mathrm{X}$ & $\mathrm{X}$ & $\mathrm{X}$ & $\mathrm{X}$ & $\mathrm{X}$ \\
\hline Children & $\mathrm{X}$ & $\mathbf{9}$ & $\mathbf{9}$ & 4 & 3 & 9 \\
\hline Wedding & 2 & $\mathbf{1 0}$ & 3 & 7 & 3 & 10 \\
\hline Others & 6 & $\mathbf{8}$ & 7 & 5 & 4 & 8 \\
\hline \hline Total & $\mathbf{3 7}$ & $\mathbf{9 9}$ & $\mathbf{9 4}$ & $\mathbf{5 3}$ & $\mathbf{5 3}$ & $\mathbf{1 0 9}$ \\
\hline Average & & 8.2 & 7.8 & 5.9 & 4.4 & 9.1 \\
\hline
\end{tabular}

$\mathbf{X}$ - portal does not offer such content

Source: own research

\section{Conclusions}

The results of this author's research and other studies presented in this paper describe the specificity of interests of Polish web-surfing women in relation to the content and functionality of web sites addressed predominantly to women. The 'standard' topics - such as health, beauty, makeup, fashion, house, children, erotica, dieting, wedding, and cuisine - should be complemented by additional content that the web-surfing women in Poland find useful and desirable. These supplementary topics include, most of all, job market information (job offers, job advertisement, job counseling), psychology, tourism, sports and recreation. It may also be useful to introduce sections for automotive news, celebrity news or legal counseling. Other topics and functionality features, such as online shopping or forums, are found to be redundant, at least in the context of general women's portals. The general evaluation of women's portals, as reported by their addressees, we can describe as 'mediocre'. Careful planning and further development needs before women's portals can reach the status of acceptable sources of content for Polish web-surfing women. The results may also be useful for e-marketing researchers, managers of business and non-business online enterprises, Internet sociologists and demographers, politicians, and others. 


\section{References}

Badanie Megapanel PBI/Gemius. (2006). Retrieved August 12, 2007 fro m http://panel.pbi.org.pl/wyniki.

Badanie Megapanel PBI/Gemius. (2007). Retrieved March 6, 2008 fro m http://panel.pbi.org.pl/wyniki.

Badanie Megapanel PBI/Gemius. (2008). Retrieved November 23, 2008 from http://panel.pbi.org.pl/wyniki.

Boyd, D., \& Ellison, N. (2007). Social network sites: Definition, history, and scholarship. Journal of Computer-Mediated Communication, 13(1), article 11. Retrieved October 24, 2008 from http://jcmc.indiana.edu/voll3/issue 1/boyd.ellison

Geidner, N.W., Flook, C. A., \& Bell, M. W. (2007). Masculinity and online social networks: Male selfidentification on Facebook.com. Eastern Comm. ASS., $98^{\text {th }}$ Annual Meeting, Providence, RI, USA

Malachowski, A. (2005). Virtual customer environment (in Polish). AE Wroclaw.

Mendes, M., Sou mi, R., \& Passos C. (2004). Digital communities in a networked society. New York: Kluwer.

Nielsen, J. (2003). Projektowanie funk cjonalnych serwisow internetowych. Helion Gliwice.

Nielsen, J., \& Loranger, H. (2007). Optymalizacja funkcjonalnosci serwisow internetowych. Helion, Gliwice.

Przygrodzka, P. (2008). Organizacja i funkcjonowanie portali internetowych w spotecznosci kobiet (Organising and functioning of wo men society's web portals, in Polish), master thesis, Uniwersytet Ekonomic zny, Wroclaw.

\section{Biographies}

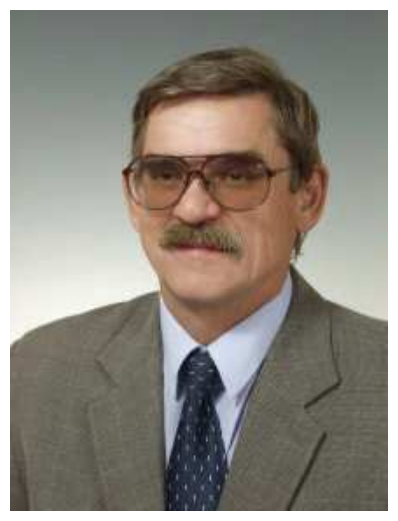

Andrzej Malachowski (*1944), Ph D. (1977) in operation research, university professor (1994). Wroclaw University of Economics (Poland), Management and Informatics Faculty, Institute of Business Informatics. Head of Business Communication Department. Main scientific interests: business informatics, e-business, business communication. On these fields author and co-author more than 20 books and 80 papers. 12 doctors degree had conferred.

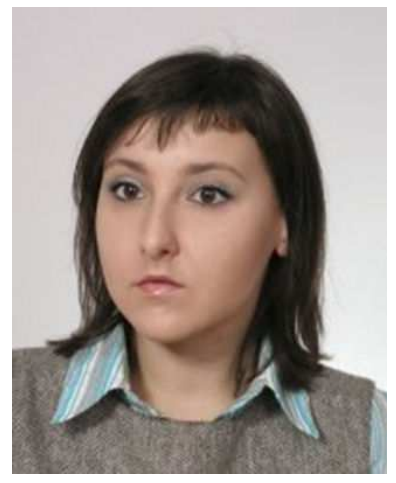

Paulina Maria Przygrodzka, master of computer science (2008), University of Economics, Faculty Management, Business Informatics an Finance Wroclaw, Poland. For the last four years working as the webmaster and content manager in one of largest web portal in Poland. Conducts after studies its own portal dedicated to polish women- Lejdis.pl 